\title{
KAJIAN LITERATUR ANALISIS KOMPETENSI PENGEMUDI MENGEMUDIKAN KENDARAAN DALAM LALU LINTAS ANGKUTAN JALAN
}

\author{
Bambang Istiyanto ${ }^{1}$ \\ ${ }^{1}$ Program Studi Manajemen Keselamata Transportasi Jalan, Politeknik Keselamatan \\ Transportasi Jalan. JI Semeru No. 3 Kota Tegal
}

\begin{abstract}
Abstrak
Mengemudi merupakan pekerjaan yang memiliki resiko yang besar, karenanya membutuhkan kompetensi berlalulintas. Kompetensi merupakan perwujudan dari pengetahuan, keterampilan, dan sikap kerja yang dimiliki oleh seseorang dalam pekerjaan tertentu. Penelitian diperlukan untuk mengembangkan pengetahuan, keterampilan dan sikap bagi pengemudi dalam mengoperasikan kendaraan dijalan. Penelitian ini bertujuan untuk menganalasis kompetensi pengemudi untuk mengoperasikan kendaraan dalam berlalulintas. Metode yang dipergunakan dengan melakukan kajian teori dari beberapa penelitian yang sudah dilakukan oleh para peneliti terdahulu. Hasil dari penelitian ini merupakan kompetensi pengemudi meliputi pengetahuan, keterampilan, dan sikap dalam mengoperasikan mobil di jalan. Kompetensi ini dipergunakan untuk membuat kurikulum pelatihan pengemudi. Penelitian lanjutan dibutuhkan untuk pengujian kebenaran kompetensi pada pelatihan pengemudi dan perubahan perilakunya.
\end{abstract}

Kata Kunci: Kompetensi, Pelatihan Mengemudi, Peraturan Berlalu Lintas

\section{PENDAHULUAN}

Seperti yang telah kita ketahui bahwa kecelakaan lalulintas dominan disebabkan oleh perilaku penggunajalan. Dalam kaitannya dengan kecelakaan yang melibatkan angkutan umum, dalam pembahasan penelitian ini adalah bus, maka factor pengemudi bus menjadi suatu hal yang perlu dikaji secara intens dalam upaya untuk dapat meningkatkan keselamatan berlalulintas.

Pengemudi merupakan orang yang mengoperasikan kendaraan bermotor di jalan yang telah memiliki surat ijin menggemudi/SIM (UU LLAJ No 22, 2009). Pengemudi menjadi pelaku utama dalam kecelakaan lalulintas di jalan. Dalam data Statistik Kecelakaan Lalu Lintas Jalan di Indonesia Tahun 2016, rata-rata pengemudi mobil yang terlibat kecelakaan dari tahun 2013-2016 memiliki SIM sebesar 77\%, sedangkan pengemudi yang tidak memiliki SIM sedesar 23\%. Mendasarkan data tersebut, kempemilikan SIM belum tentu memiliki kompetensi dalam mengoperasikan kendaraan dalam lalulintas.

Keselamatan perjalanan dipengaruhi oleh kompetensi pengemudi dalam mengendalikan kendaraan di jalan. Karakteristik pengemudi dengan informasi yang diterima memiliki interaksi yang kuat, sangat penting dibutuhkan dalam mengemudikan kendaraan bermotor dijalan (Abendroth dan Bruder, 2016). Abendroth dan Bruder juga menjelaskan bahwa kinerja manusia umumnya dicirikan oleh hasil kerja dan tuntutan beban kerja pada individu yang melaksanakan tugas. Baik hasil kerja maupun tuntutan pekerjaan sesuai dengan variasi antar dan intraindividu: tidak semua individu memenuhi tugas yang sama dan samabaiknya, tetapi 
bahkan individu dapat menunjukkan variabilitas kinerja jika kinerja tugas yang sama diukur pada titik waktu yang berbeda. Variabilitas ini dapat dikaitkan dengan karakteristik manusia individu dan dengan demikian juga untuk berbagai kondisi kinerja. Tindakan seorang pengemudi dipengaruhi oleh kapasitas mental yang didefinisikan sebagai kecerdasan, terutama pada tingkat berbasis pengetahuan. Konsep kecerdasan diperdebatkan dalam literatur. Menurut definisi yang luas, kecerdasan dipahami sebagai keseluruhan system yang terstruktur secara hierarkis dari kemampuan mental seseorang secara umum yang menentukan tingkat dan kualitas proses pemikiranseseorang. Namun demikian, kinerja sesorang dalam menuntaskan pekerjaan tidak hanya didasarkan pada kecerdasan saja, tapi dibutuhkan kemampuan motorik dan sikap kerja yang baik. Penggabungan hal-hal tersebut dikatakan dengan kompetensi. Menurut International Labor Organization (ILO), 2015, kompetensi merupakan kemampuan untuk melakukan tugas dan tugas tertentu sesuai standar kinerja yang diharapkan di tempa tkerja, menerapkan semua keterampilan, pengetahuan, dan sikap yang relevan secara konsisten dari waktu kewaktu dalam situasi tempat kerja yang dibutuhkan.

\section{LANDASAN TEORI}

Konsep tentang kompetensi yang ditulis Jarvis 1985 yang disampaikan oleh Kennedy, Hyland, dan Ryan, 2009 bahwa analisis konsep kompetensi dapat membantu untuk memberikan dasar di mana kurikulum dapat dibangun dan menunjukkan bahwa ini akan memiliki tiga komponen :

1. Pengetahuan dan pemahaman disiplin akademis yang relevan, unsur-unsur psikomotor, keterampilan interpersonal, nilai-nilai moral.

2. Keterampilan untuk melakukan teknik psikomotorik, berinteraksi dengan anggota peran.

3. Sikap yang menghasilkan pengetahuan dan komitmen untuk profesionalisme, kesediaan untuk memainkan peran secara profesional.

Sanghi, 2007, mendefinisikan kompetensi adalah komponen pekerjaan yang tercermin dalam perilaku yang dapat diamati di tempat kerja. Unsur-unsur umum yang paling sering disebutkan adalah pengetahuan, keterampilan, kemampuan, bakat, perilaku kesesuaian pribadi dan dampak pada kinerja di tempat kerja. Ada berbagai definisi dengan sedikit perbedaan di dalamnya. Namun, denominasi umum adalah 'perilaku yang dapat diamati' di tempat kerja. Kriteria kompetensi adalah kinerja yang unggul dan kinerja yang efektif. Hanya beberapa kompetensi yang dapat memprediksi kinerja. Kompetensi bukanlah kinerja tetapi merupakan suatu keadaan, suatu kualifikasi untuk dilaksanakan. Hal ini, dalam kaitannya dengan kinerja, kondisi yang diperlukan tetapi tidak cukup. Pekerja tidak dapat melakukan standar tanpa kompetensi. Tetapi kompetensi tidak dapat menjamin bahwa pekerja akan bekerja dengan baik. Terkadang, pekerja yang sangat kompeten mungkin gagal dalam pekerjaan karena berbagai faktor pribadi atau lingkungan. Mereka yang kurang kompeten dapat menggantikan banyak kekurangan dengan kerja yang sangat keras. Kompetensi harus ada di sana tetapi tidak bisa menjamin hasil, juga tidak bisa ketiadaan selalu memprediksi kegagalan. Pengukuran kompetensi tidak harus bingung dengan pengukuran kinerja. Kompetensi adalah tentang memenuhi syarat untuk melakukan pekerjaan dalam posisi tertentu. Kinerja, di sisi lain, adalah hasil dari pekerjaan yang sebenarnya. Model kompetensi juga memungkinkan 
pengembangan sistem penilaian yang mengevaluasi orang-orang tentang penggunaan perilaku dan praktik mereka yang secara langsung berkontribusi pada daya saing, mendorong baik bisnis maupun individu untuk fokus pada apa pun yang akan memiliki dampak terbesar.

Mengendarai kendaraan dalam lalu lintas biasa merupakan aktivitas yang secara inheren berbahaya bagi pengemudi, penumpang, dan pejalan kaki. Ada harapan bahwa pengemudi akan mempertahankan jarak yang tepat dari satu sama lain dan dari benda mati dan pejalan kaki. Kendaraan yang melakukan perjalanan dengan kecepatan tinggi dalam jarak dekat satu sama lain dan kepada pengguna jalan lainnya menghadirkan potensi bencana karena sejumlah besar energi kinetik yang hilang ketika tabrakan antara dua atau lebih objek dapat dengan mudah menyebabkan cedera atau kematian. Di negara-negara maju secara ekonomi, mengemudi adalah salah satu kegiatan paling berbahaya yang secara rutin dilakukan oleh sebagian besar penduduk. Mungkin satu-satunya kegiatan yang sebanding yang memiliki risiko cedera atau kematian yang lebih tinggi adalah menjadi pejalan kaki versus sopir atau penumpang di dalam kendaraan. Risiko terluka parah atau terbunuh secara signifikan lebih besar untuk pejalan kaki karena mereka tanpa perlindungan apa pun, tidak seperti penghuni kendaraan, yang jika terjadi kecelakaan memperoleh perlindungan signifikan dari infrastruktur keselamatan kendaraan mereka sendiri (misalnya, zona crumple, sabuk pengaman, dan airbag ), terutama jika kendaraan dirancang untuk sangat crashworthy.

Michon, dalam Macdonald, Joseph, Marilyn, 2006 mendeskripsikan kinerja dan perilaku mengemudi dalam tiga tingkat hierarkis: operasional, taktis, dan strategis. Perilaku operasional berkaitan dengan manuver kendaraan rutin pada tingkat operasi pengendalian kendaraan; sehingga umumnya pada tingkat berbasis keterampilan (dalam hal SRK) kecuali untuk driver pemula. Perilaku taktis adalah yang terlibat dalam penerapan aturan jalan dan beradaptasi dengan tuntutan kondisi jalan dan lalu lintas segera, termasuk kinerja manuver seperti belokan, menyalip, dan parkir; ini dapat dilakukan pada berbagai tingkat otomatisasi, tetapi kebanyakan pada tingkat berbasis aturan untuk sebagian besar pengemudi. Perilaku strategis mempertimbangkan tujuan dan konteks mengemudi yang lebih umum, termasuk keputusan tentang apakah mengemudi di bawah kondisi tertentu dan perencanaan rute; ini paling sering pada tingkat berbasis pengetahuan. Kerangka kerja ini bersifat hierarkis, menspesifikasikan kompetensi pengemudi dan atribut dalam kategori berikut: kompetensi mengemudi spesifik dan karakteristik driver prasyarat. Secara spesifik kompetensi mengemudi dapat dijelaskan sebagai berikut :

- Strategi pengemudi umum: Tujuannya adalah untuk mengoptimalkan keseimbangan antara eksposur individu terhadap risiko cedera dan mobilitas komunitasnya, serta memaksimalkan kemampuan pribadi untuk berkendara dengan aman.

- Taktik mengemudi di jalan: Tujuan mereka adalah untuk mencapai tujuan keseluruhan dari perjalanan sambil juga mengoptimalkan keseimbangan antara tuntutan tugas mengemudi dan kemampuan individu untuk berkendara dengan aman dan sesuai dengan hukum jalan.

Pengendalian operasi kendaraan: Tujuan mereka adalah pelaksanaan yang tepat dari elemen kinerja yang terlibat dalam operasi pengendalian kendaraan dasardan maneuver. 


\section{Pendidikan Dan Pelatihan Mengemudi}

Di Indoensia, untuk mengemudikan kendaraan bermotor di jalan harus memiliki surat ijin mengemudi (SIM), sebagaimana di atur dalam Undang - Undang Nomor 22 Tahun 2009 Tentang Lalu Lintas dan Angkutan Jalan Pasal 77. Untuk mendapatkan SIM harus memiliki kompetensi mengemudi yang diperoleh melalui pendidikan dan pelatihan atau belajar sendiri. Hal ini diperjelas dalam Peraturan Kapolri No 9 Tahun 2012 Tentang Surat Ijin Mengemudi, untuk mendapatkan SIM harus melalui ujian teori dan ujian, keterampilan mengemudi melalui simulator dan praktek.

a. Materi yang dalam ujian teori meliputi :

- hak utama pengguna jalan; iscep:

- pengetahuan tentang rambu lalu lintas, marka jalan, alat pemberi isyarat lalu lintas, dan gerakan lalu lintas; istep:

- kedudukan hukum lalu lintas; dan isip:

- peringatan sinar dan bunyi. isẹp?

b. Keterampilan pengemudi dengan materi meliputi :

- cara mengemudi kendaraan bermotor; isE?

- cara mendahului kendaraan bermotor lain; isçp?

- cara berbelok; iske?

- cara melewati persimpangan; isep?

- cara penggunaan lampu kendaraan bermotor; istep

- cara penggandengan dan penempelan kendaraan lain; is:ep:

- cara parkir; istep?

- cara berhenti; istipi:

- kecepatan minimal dan maksimal; dan icspi

- cara penggunaan jalur dan lajur Jalan; is:

c. Etika berlalu lintas, meliputi :

- hak dan kewajiban pengemudi dan pengguna jalan lain; dan sise:

- tanggung jawab pengemudi; ;sicp:

d. Pengetahuan teknik kendaraan bermotor

e. Pertolongan pertama pada kecelakaan lalu lintas.

Kompetensi mengemudi tersebut di atas, diperoleh oleh melalui sekolah mengemudi dan belajar sendiri. Belum diatur secara detail, namun dibuat kurikulum tentang Kursus dan Pelatihan Mengemudi Kendaraan Bermotor untuk Pemula Jenjang II Berbasis Kerangka Kualifikasi Nasional Indonesia oleh Kementerian Pendidikan dan Kebudayaan. Dalam kurikulum tersebut, terdapat profil lulusan sebagai berikut, "profil lulusan pelatihan pengemudi pemula yang memiliki kemampuan meliputi karakter dan kepribadian manusia Indonesia, mengemudikan dan mengendalikan kendaraan bermotor secara mandiri, menguasai pengetahuan prosedural, faktual, prinsip-prinsip tentang kendaraan dan teknik berkendaraan ringan dan bertanggung jawab atas pekerjaan sebagai pengemudi pemula dalam mewujudkan keamanan, keselamatan, ketertiban dan kelancaran (kamseltibcar) lalu lintas baik bagi dirinya sendiri, pengguna jalan lain maupun masyarakat di lingkungan sekitarnya". Dengan capaian pembelajaran sebagai berikut : 
Tabel 1. Capaian Pembelajaran

\begin{tabular}{|c|c|}
\hline Sikap dan Tata Nilai & 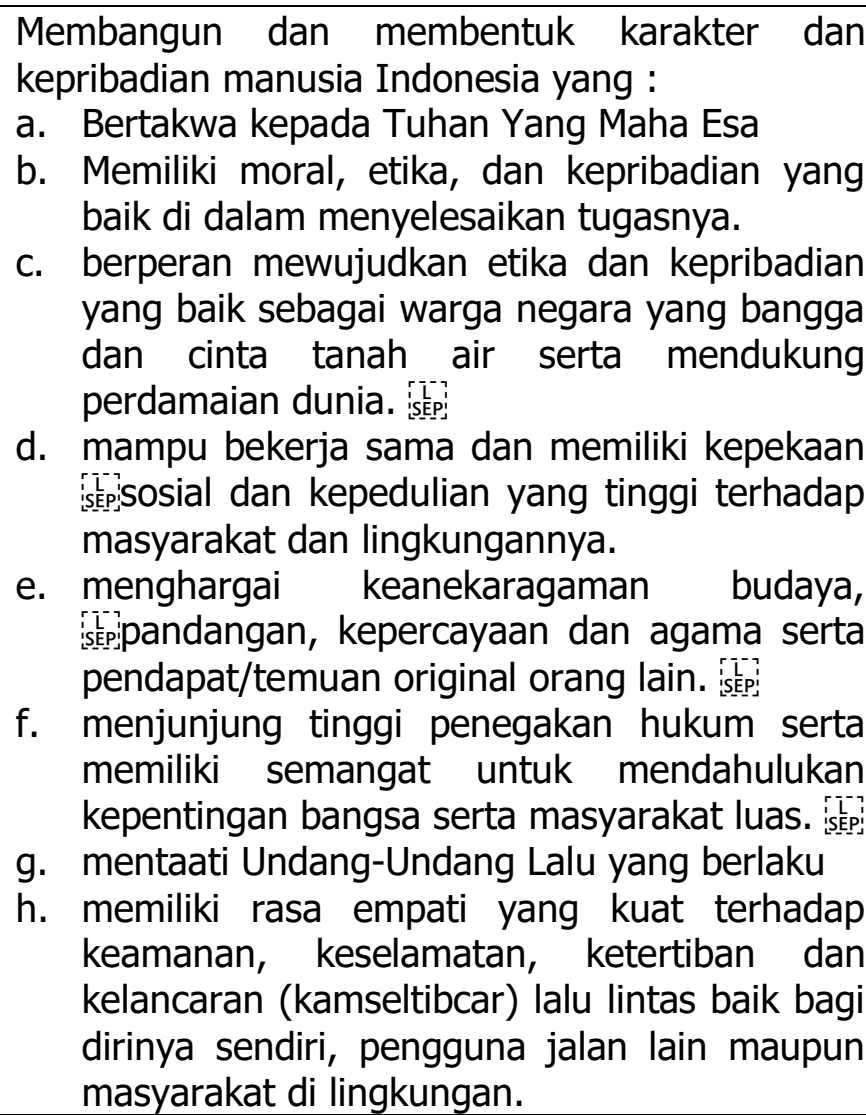 \\
\hline $\begin{array}{l}\text { Kemampuan di Bidang } \\
\text { Kerja }\end{array}$ & 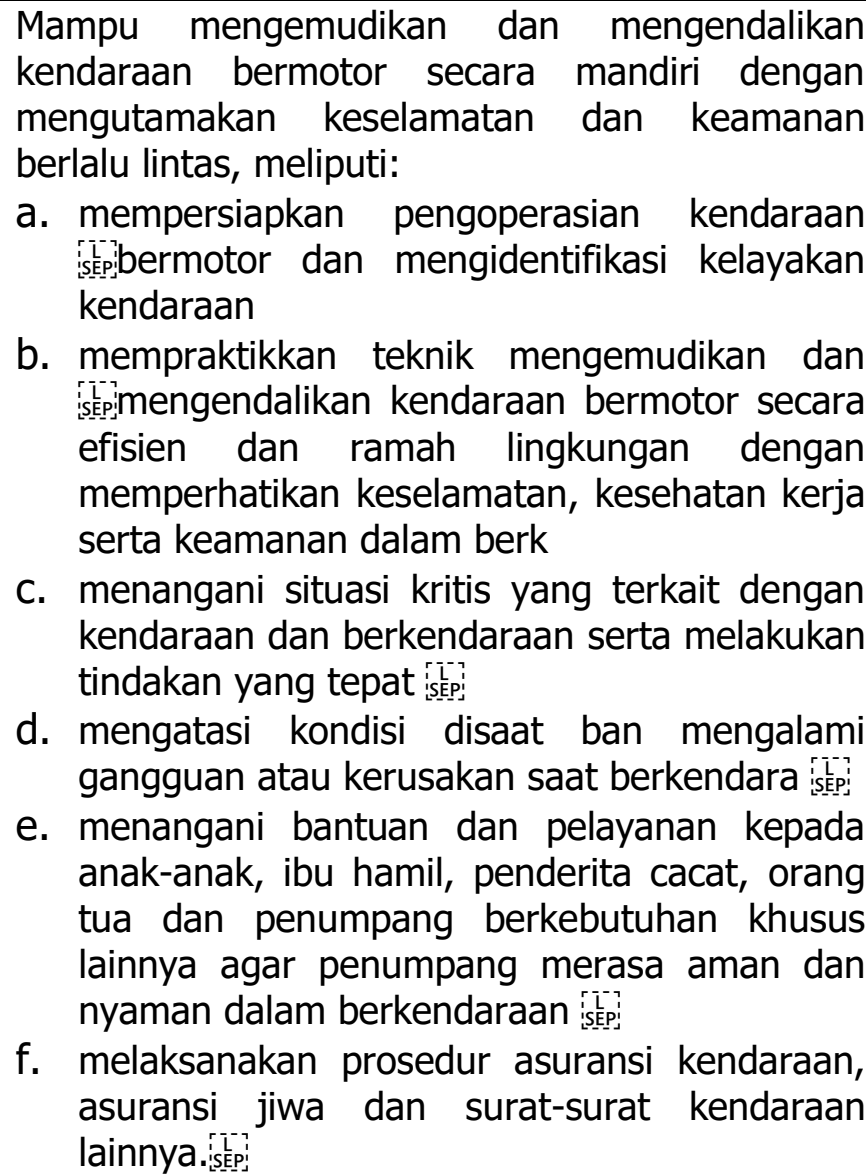 \\
\hline
\end{tabular}




\begin{tabular}{|c|c|}
\hline $\begin{array}{l}\text { Pengetahuan } \\
\text { Dikuasai }\end{array}$ & 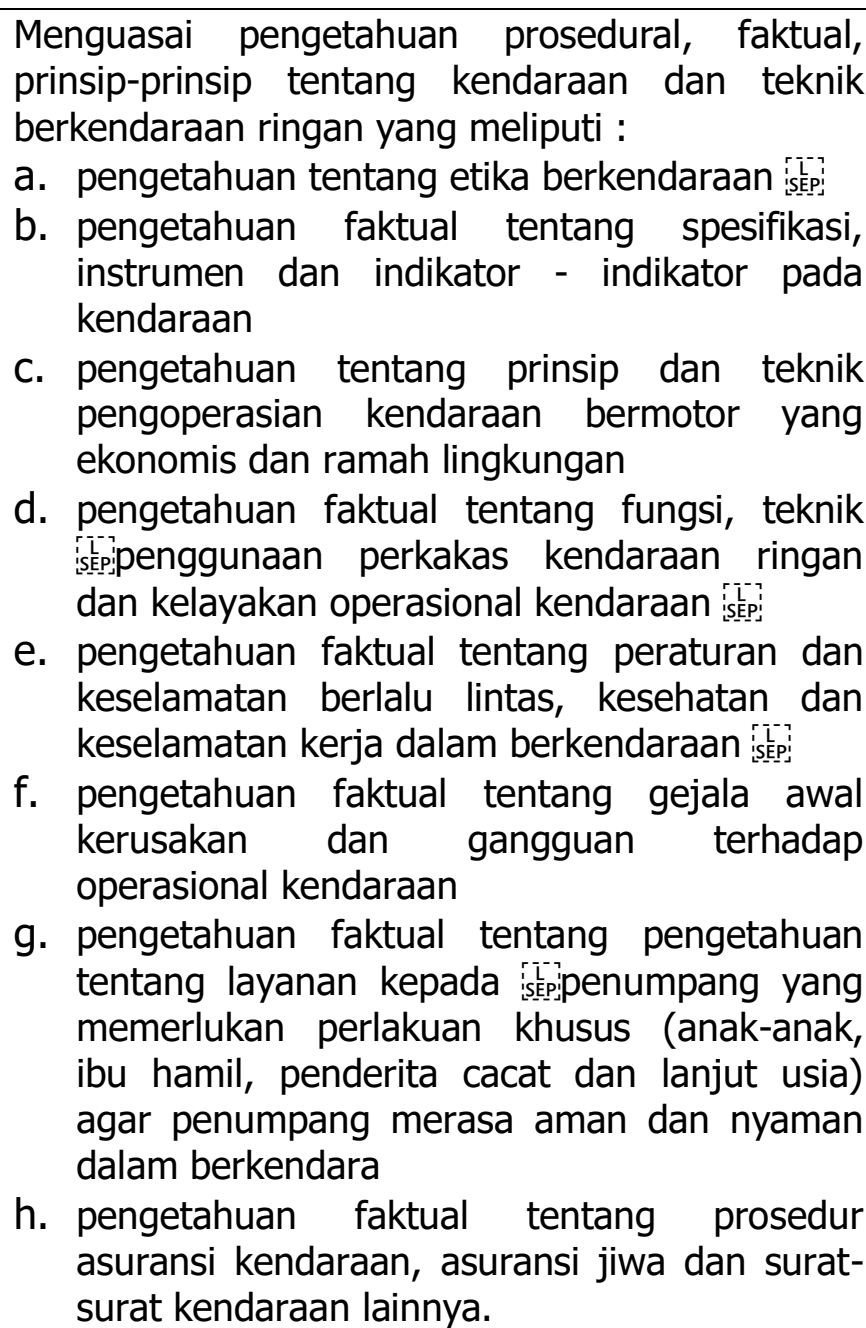 \\
\hline $\begin{array}{ll}\text { Hak } & \text { dan } \\
\text { Tanggungjawab } & \end{array}$ & 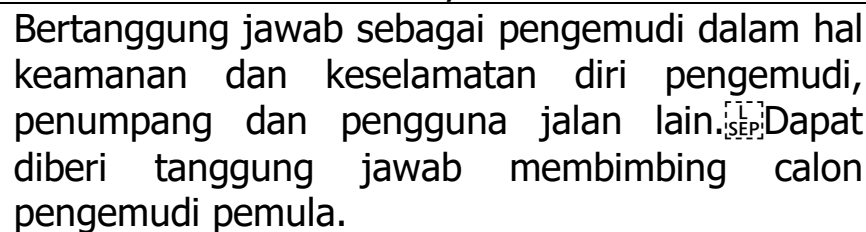 \\
\hline
\end{tabular}

\section{METODE PENELITIAN}

Kajian referensi hasil penelitian di Indonesia terkait dengan kompetensi pengemudi belum banyak dilakukan, pencarian ini dengan menggunakan google.com. Hal ini berbeda ketika dibandingkan dengan yang ada di luar negeri sudah banyak penelitian yang membahas tentang kompetensi pengemudi. Hasil temuan yang dari penelitian ini dibahas untuk kepentingan analisis kompetensi dalam mengemudikan kendaraan bermotor di jalan.

\section{PEMBAHASAN}

Semua pekerja ini menghadapi risiko di jalan karena mereka melakukan pekerjaan mereka. Mereka juga dapat menciptakan risiko bagi orang lain di jalan. Data kecelakaan jalan polisi menunjukkan bahwa setiap tahun lebih dari 26.000 orang tewas, 22.000 luka berat dan hampir 120.000 luka ringan dalam tabrakan yang melibatkan pengemudi atau pengendara yang mengemudi untuk bekerja. 
Dalam data Statistik Kecelakaan Lalu Lintas Jalan di Indonesia Tahun 2016, rata-rata pengemudi mobil yang terlibat kecelakaan dari tahun 2013-2016 memiliki SIM sebesar $77 \%$, sedangkan pengemudi yang tidak memiliki SIM sedesar $23 \%$. Dilihat dari presentasi ini pelaku kejadian kecelakaan memiliki kompetensi sesuai dalam Peraturan Kapolri No 9 Tahun 2012, dimana SIM merupakan bukti kompetensi pengemudi dalam berlalulintas. Besarnya pemilik SIM terlibat dalam kejadian kecelakaan lalu lintas di Indonesia dapat dimaknai bahwa pengemudi masih belum mengaplikasikan kompetensinya sepenuhnya dalam berlalu lintas.

Pengemudi di Indonesia sebagaimana tercantum dalam pedoman kursus yang dikeluarkan dikti mendapatkan pengetahuan dan keterampilan yang lebih rendah levelnya pada jenjang II di level KKNI. Melihat tugas yang lebih berat sebagaimana dituliskan oleh Josep, 2006, dimana pengemudi memiliki tanggungjawab dalam mengoptimalkan keseimbangan antara eksposur individu terhadap risiko cedera dan mobilitas komunitasnya, serta memaksimalkan kemampuan pribadi untuk berkendara dengan aman, mencapai tujuan keseluruhan dari perjalanan sambil juga mengoptimalkan keseimbangan antara tuntutan tugas mengemudi dan kemampuan individu untuk berkendara dengan aman dan sesuai dengan hukum jalan, dan pelaksanaan yang tepat dari elemen kinerja yang terlibat dalam operasi pengendalian kendaraan dasar dan maneuver.

\section{KESIMPULAN DAN SARAN}

Pengemudi di Indonesia sebagaimana tercantum dalam pedoman kursus yang dikeluarkan dikti mendapatkan pengetahuan dan keterampilan yang lebih rendah levelnya pada jenjang II di level KKNI. Melihat tugas yang lebih berat sebagaimana dituliskan oleh Josep, 2006, dimana pengemudi memiliki tanggungjawab dalam mengoptimalkan keseimbangan antara eksposur individu terhadap risiko cedera dan mobilitas komunitasnya, serta memaksimalkan kemampuan pribadi untuk berkendara dengan aman, mencapai tujuan keseluruhan dari perjalanan sambil juga mengoptimalkan keseimbangan antara tuntutan tugas mengemudi dan kemampuan individu untuk berkendara dengan aman dan sesuai dengan hukum jalan, dan pelaksanaan yang tepat dari elemen kinerja yang terlibat dalam operasi pengendalian kendaraan dasar dan maneuver.

\section{DAFTAR PUSTAKA}

Abendroth, B., Bruder, B., 2016, Capabilities of Humans For Vehicle Guidance dalam Handbook Driver Assistance System, Basic Information Components And System For Active Safety And Comfort.

Direktorat Pembinaan Kursus dan Pelatihan, Dirjen PAUD dan Pendidikan Masyarakat, Kementerian Pendidikan dan Kebudayaan, 2015, Kursus dan Pelatihan Mengemudi Kendaraan Bermotor untuk Pemula Jenjang II Berbasis Kerangka Kualifikasi Nasional Indonesia.

Intertional Labor Organization, 2015, Regional Model Competency Standard: Core Competecies, ILO Regional Office for Asia and the Pacific, Regional Skills Programme, ILO Regional Office for Asia and the Pacific. Bangkok : ILO, 2015 
Kennedy, D., Hyland, A., Ryan, N., 2009, Learning Outcomes and Competences dalam Introducing Bologna objectives and Tools, B 2.3-3, BH 11309 09,

Kepolisian Republik Indonesia, 2012, Peraturan Kepala Kepolisian Negara Republik Indonesia, Nomor 9 Tahun 2012, Berita Negara Republik Indonesia Tahun 2012.

Korps Lalu Lintas Kepolisian Republik Indonesia, 2016, Statistik Kecelakaan Lalu Lintas Jalan di Indonesia Tahun 2016.

Lembaran Negara Republik Indonesia Tahun 2009 Nomor 96, Undang - Undang No 22 Tahun 2009 Tentang Lalu Lintas dan Angkutan Jalan

Joseph M. Pellerito, Jr. dan et.all, 2006 , Driver Rehabilitation and Community Mobility, Elsevier Mosby, 11830 Westline Industrial Drive St. Louis, Missouri 63146, United States of America. 